\title{
Imaging a magma plumbing system from MASH Zone to magma reservoir
}

\author{
Jonathan R. Delph ${ }^{1,2 *}$, Kevin M. Ward ${ }^{1,3}$, George Zandt ${ }^{1}$, Mihai N. Ducea ${ }^{1,4}$, Susan L.
} Beck $^{1}$

1. Department of Geosciences

The University of Arizona

1040 E. $4^{\text {th }}$ Street

Tucson, AZ, USA, 85721

2. Now at: Department of Earth Science

Rice University

6100 Main Street

Houston, TX, USA, 77005

3. Now at: Department of Geology and Geophysics

The University of Utah

115 S. 1460 E.

Salt Lake City, UT, USA, 84112

4. Faculty of Geology and Geophysics

University of Bucharest

Strada N. Balcescu Nr 1

Bucharest, Romania, 010041

Corresponding Author

jrdelph@rice.edu

\section{Abstract}

2 The Puna Plateau of the Central Andes is a well-suited location to investigate

3 the processes associated with the tectono-magmatic development of a Cordilleran

4 system. These processes include long-lived subduction (including shallow and steep

5 phases), substantial crustal thickening, the emplacement of large volumes of

6 igneous rocks, and probably delamination. To elucidate the processes associated

7 with the development of a Cordilleran system, we pair Common Conversion Point-

8 derived receiver functions with Rayleigh wave dispersion data from Ambient Noise

(C) 2016. This manuscript version is made available under the Elsevier user license 
9 Tomography. The resulting high-resolution shear wave velocity model of the

10 southern Puna Plateau reveals the details of a lithospheric-scale magma plumbing

11 system. Slow velocities near the crust-mantle transition are interpreted as a MASH

12 Zone (a partially molten zone where mantle-derived melts interact with the

13 lithosphere and undergo density differentiation) with $\sim 4-9 \%$ melt. After

14 differentiation, less dense and presumably more felsic melts propagate to shallower

15 depths within the crust ( $\sim 20 \mathrm{~km}$ below surface) and comprise vertically ( $\sim 10 \mathrm{~km})$

16 and laterally $(\sim 75 \mathrm{~km})$ extensive slow velocity bodies that span the frontal arc and

17 plateau interior. These large slow velocity bodies represent a partially molten mid-

18 crust (up to 22\%) where magma can further evolve to higher silica concentrations.

19 The periodic influx of melt from the underlying MASH zone into these mid-crustal

20 bodies may serve as a trigger to the eruption of the voluminous ignimbrites

21 observed in the southern Puna Plateau. Many of the active tectonic processes

22 operating along the southern Puna Plateau are thought to be analogous to the

23 processes that formed the North American Cordillera. Thus, these results could

24 provide insight into some of the processes associated with the development of a

25 Cordilleran margin.

26 Keywords: Cordillera; Andes; Magmatic Arcs; Seismology; Crustal Structure

\section{Introduction}

29 Spatially extensive subduction-related magmatic products form at Andean

30 (Cordilleran) margins. The spatial footprint of magmatism is complicated by long-

31 term subduction, frontal arc migration, and changes in upper plate deformation over 
32 time, all of which lead to various types of magmatic additions to the crust (DeCelles

33 et al., 2009). The intrusion of large igneous bodies are the aggregate result of long

34 term subduction at an Andean margin and represent the roots of frontal arcs and

35 interior volcanism generally characterized by the eruption of felsic-intermediate

36 ignimbrites (Ducea et al., 2015c; Best et al., 2009; Freymuth et al., 2015) . Despite in-

37 depth petrological studies of Cordilleran-type frontal arcs and neighboring interior

38 magmatism (Saleeby et al., 2003; Lipman and Bachmann, 2015; Ducea et al., 2015c;

39 Best et al., 2016), vertically extensive seismic images of magma plumbing systems

40 have only recently been resolved thanks to improvements in seismic coverage and

41 imaging techniques (Ward et al., 2014; Huang et al., 2015; Kiser et al., 2016). An

42 active type-example of these melt-forming and storing systems can be found in the

43 South American Cordillera, where large-scale intermediate/felsic volcanism and

44 ignimbrite flare-ups are thought to be the surface expression of batholith formation

45 at depth (de Silva and Gosnold, 2007). Evidence is mounting from both petrological

46 and geophysical data that large-scale igneous bodies stall in the mid-crust and

47 undergo further crystal fractionation and mixing with crustal material as they

48 transition from their more mafic initial compositions to felsic compositions (Kay et

49 al., 2011; Ward et al., 2014; Comeau et al., 2015; Ducea et al., 2015a; Huang et al.,

50 2015; Best et al., 2016). If these ponded magma reservoirs are laterally extensive,

51 seismic imaging of these melt bodies is possible (Zandt et al., 2003; Ward et al.,

52 2014).

53 Regions with long-lived volcanic activity are thought to be underlain by a

54 Melting, Assimilation, Storage, and Homogenization (MASH) zone at the base of the 
55 crust (Hildreth and Moorbath, 1988). The MASH zone represents a level of neutral

56 buoyancy for mantle-derived basaltic melt where fractionation, differentiation, and

57 mixing with lower crustal material occurs. This lower-crustal mixing zone

58 eventually differentiates based on density, with the intermediate and felsic

59 compositions rising to shallower depths in the crust and the mafic-ultramafic

60 residuals or "cumulates" remaining near the base of the crust or sinking back into

61 the mantle (Hildreth and Moorbath, 1988; Saleeby et al., 2003). Despite the

62 petrologic evidence that these MASH zones exist beneath volcanically active regions,

63 high-resolution seismic images of these zones are difficult to obtain.

64 The southern Puna Plateau was the site of a passive seismic experiment

65 deployed from 2007 to 2009 by US, German, Argentine and Chilean institutions (Fig.

66 1) (Bianchi et al., 2013). Numerous seismic studies using different techniques,

67 including teleseismic and regional distance body wave tomography (Bianchi et al.,

68 2013), P- and S-wave receiver functions (Heit et al., 2014), two plane-wave

69 tomography using earthquake-generated surface waves (Calixto et al., 2013), and

70 body wave attenuation (Liang et al., 2014), characterize the first-order lithospheric

71 structure and identify some important magmatic features in the region. However,

72 the techniques utilized in these studies have some inherent resolution limitations

73 within the crust.

74 We utilize a recently developed technique for the joint inversion of receiver

75 functions and surface-wave dispersion data (Julia et al., 2000; Delph et al., 2015)

76 from this dense array of seismic stations to obtain a 3D shear wave velocity model

77 of this magmatically-active subduction-related continental plateau. This resulting 
78 model has better crustal resolution than previous models and illuminates a

79 magmatic plumbing system from the base of the lithosphere to the upper levels of

80 the crust. We interpret these images in the context of the detailed tectonic and

81 petrologic history of the southern Puna Plateau to understand the evolution of the

82 continental lithosphere through subduction-related processes (e.g. the

83 compositional variation of igneous rocks, plutonic-volcanic (P:V) ratios, and

84 lithospheric foundering). As the western margin of South America is often

85 interpreted as a modern analogue to the North American Cordillera, these results

86 have broad implications for long-lived magmatic arcs and the development of

87 Cordilleran systems.

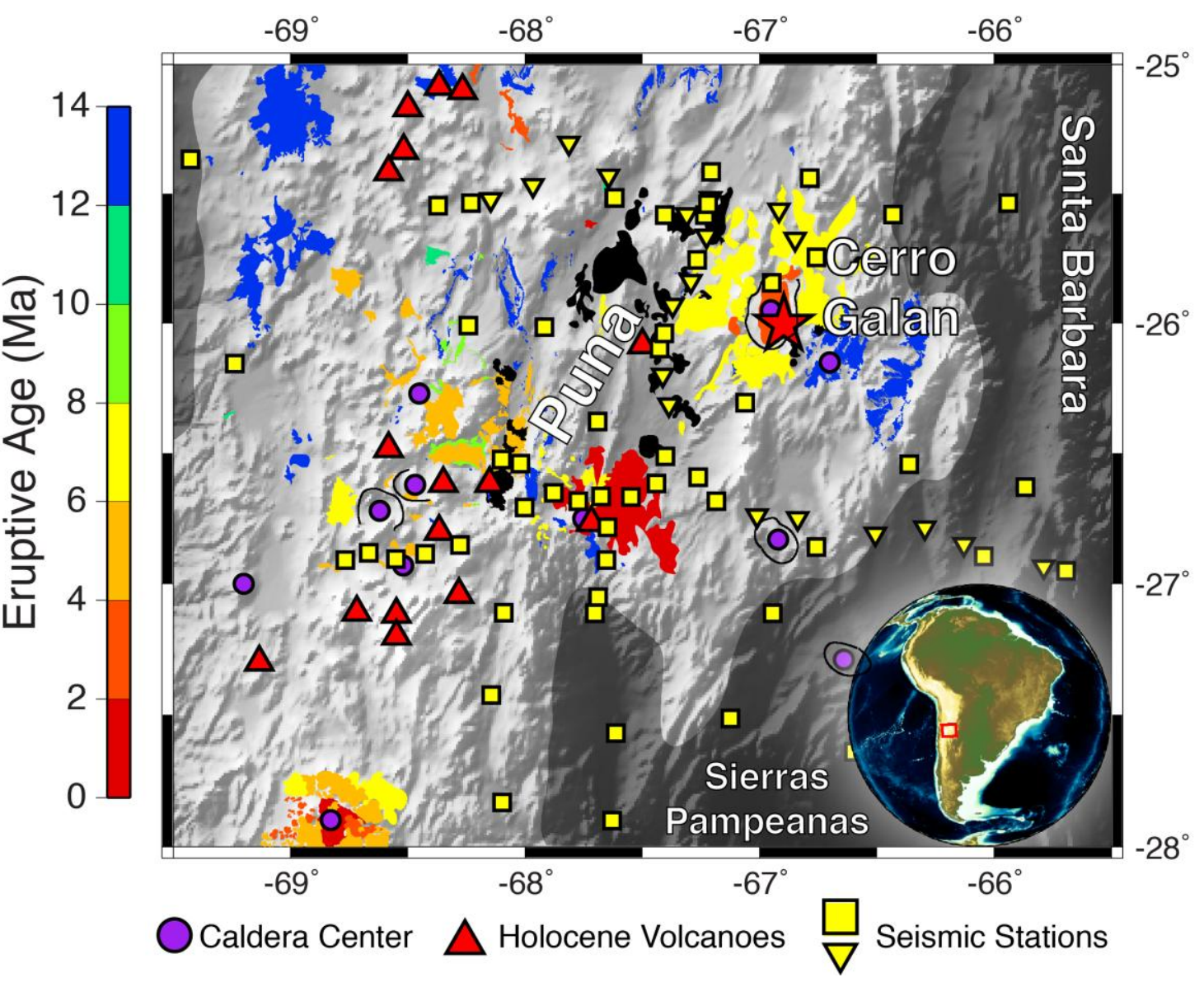


89 Figure 1: The seismic station distribution (yellow squares: intermediate or

90 broadband stations; inverted triangles: short-period stations) in the southern Puna

91 Plateau and surrounding region. Elevations $>3 \mathrm{~km}$ represent the southern Puna

92 Plateau (unshaded). Only stations that had high-quality receiver functions are

93 plotted. Irregularly shaped polygons represent ignimbrite deposits colored by

94 eruptive age, and black semi-circular lines represent mapped ignimbrite calderas

95 (from the Andes Ignimbrite Database, Freymuth et al., 2015 and refs. therein). Black

96 units are basaltic deposits mapped at the surface, many of which show a

97 geochemical signature for delamination (Kay et al., 1994; Ducea et al., 2013; Murray

98 et al., 2015). Red star represents location of shear velocity profile in Fig. 4 within the

99 Cerro Galan Caldera.

100

101 2. Methods

$102 \quad 2.1$ Receiver Function Computation

103 This dataset arises from the analysis of 92 short, intermediate, and

104 broadband period range stations deployed from throughout the southern Puna

105 Plateau from the REFUCA project (19 stations, 2002-2003) and the complimentary

106 German - American - Chilean - Argentine projects of PUDEL (PUna DELamination)

107 and SLIP (Seismic Lithospheric Imaging of the Puna Plateau; Sandvol \& Brown

108 2007) that operated from 2007-2009. We computed 5919 receiver functions from

109 earthquakes with magnitudes between 5.5 and 7.6 from distances between 30 and

11090 degrees.

111 For short period instruments, the instrument response was deconvolved

112 from the waveforms to enhance the sensitivity to lower frequency signals in the

113 seismograms (Niu et al. 2005). The short period data was kept in units of velocity

114 and incorporated into the larger dataset (Fig. 2A). All traces were then filtered to

115 enhance the frequency range of interest and those that did not display clear first

116 arrivals were discarded from further analysis. Radial receiver functions were

117 computed using the iterative time-domain receiver function computation described 
118 by Ligorria \& Ammon (1999). We used a Gaussian pulse width of 2.5 due to its

119 ability to resolve robust crustal structures (vertical resolution of $\sim 1 \mathrm{~km}$ ). The

120 receiver functions were then inspected using the FuncLab package (Eagar and

121 Fouch 2011) for further quality control.

\section{$122 \quad 2.2$ Ambient Noise Tomography}

123 The ambient noise tomography dataset of Ward et al. (2013) was augmented

124 by recently available data from the PUDEL (Heit et al., 2007), SLIP (Sandvol and

125 Brown, 2007), and PLUTONS (West and Christensen, 2010) deployments. These

126 datasets were processed as described by Ward et al. (2013) to obtain phase

127 velocities at 13 periods between 8 and 50 seconds (Supp. Fig. S1). To assure only

128 high quality data was used in the calculation of phase velocities, all cross-

129 correlations with a signal-to-noise ratio $<10$, an interstation spacing of $<3$ times the

130 wavelength at the period of interest, and unrealistic phase velocities $(<1.5 \mathrm{~km} / \mathrm{s}$ and

$131>5 \mathrm{~km} / \mathrm{s}$ ) were discarded from the 2-D phase velocity inversion (Barmin et al.,

132 2001). Also, any data that had residuals $>3$ seconds after the 2-D tomographic

133 inversion were also discarded. The resulting dispersion model has a spatial

134 resolution of $\sim 0.25^{\circ}$ based on the Rayleigh criterion (Barmin et al., 2001), and a 50

$135 \mathrm{~km}$ Gaussian smoothing parameter was used to stabilize of the inversion. Thus,

136 amplitudes $<50 \mathrm{~km}$ may be underestimated in the phase velocity results. Because of

137 the station geometry available previous to this study, the inclusion of the newly

138 available data imposed few changes to the phase velocity results of Ward et al.

139 (2013), and the period range used in this study has good sensitivities down to $\sim 80$ 
140 km (Fig. 3). PLUTONS data were not included in the receiver function analysis, as

141 they were located outside our study area.

\section{$142 \quad 2.3$ CCP-derived Receiver Function Computation}

143 We use the approach described by Delph et al. (2015) to create receiver

144 functions from Common Conversion Point (CCP) stacking analysis (Dueker \&

145 Sheehan 1997). This approach has the advantage that it maps receiver functions

146 back to their theoretical locations in the Earth and linearly stacks the amplitudes of

147 receiver functions that fall within a limited cell to create a 3D volume of impedance

148 contrasts throughout the study area. This helps correct for backazimuthal structural

149 variations beneath a station and decreases noise present in the receiver functions.

150 In our CCP stacking analysis, the spatial dimensions of the cells over which to

151 average the receiver function amplitudes have a minimum dimension of $0.2^{\circ}$

152 laterally by $0.5 \mathrm{~km}$ vertically. We allow the lateral dimension of our bins to dilate in

153 increments of $0.1^{\circ}$ until 10 rays are incorporated into the bin or a width of $1^{\circ}$ is

154 reached. A bin-spacing of $0.1^{\circ}$ is used to match the spacing of the ambient noise

155 tomography volume. We use a simple 1D velocity model consisting of $65 \mathrm{~km}$ thick

156 crust with a $6.1 \mathrm{~km} / \mathrm{s}$ P-wave velocity and a $1.74 \mathrm{Vp} / \mathrm{Vs}$ ratio, and a mantle of 7.5

$157 \mathrm{~km} / \mathrm{s}$ P-wave velocity with a Vp/Vs of 1.78 to migrate receiver functions to depth.

158 While assuming a 1D velocity model throughout the study area is an

159 oversimplification, the velocity model used in the computation of the CCP stacks will

160 have a very small effect on our resulting CCP-derived receiver functions, as we

161 migrate our CCP stacks back to time using the same velocity model. 
163 beneath a station. This leads a higher likelihood of data from different stations being

164 incorporated into the same bin and increases the spatial resolution of the receiver

165 functions with depth. However, the incorporation of data into a vertical profile that

166 may not have been present in shallower depth bins can lead to unrealistic amplitude

167 jumps in the resulting CCP-derived receiver functions that have a non-Gaussian

168 shape (Fig. 2B, black line). To reconcile this, Delph et al. (2015) used wide bin

169 widths to decrease the effect that these amplitude artifacts could have on the

170 resulting shear wave velocity profiles when jointly inverted with dispersion data. In

171 order to make this approach more robust and allow finer lateral resolution, we

172 modify the approach presented by Delph et al. (2015) to filter out spurious

173 amplitude changes and obtain a smooth waveform that can be accurately modeled

174 by the forward problem of the receiver function portion of the joint inversion.

\section{$175 \quad$ 2.3.1 Gaussian Filtering of CCP-derived Receiver Function}

176 Receiver functions can be generalized as the difference in a recorded signal

177 between a radial-component seismogram and a vertical-component seismogram

178 convolved with a Gaussian pulse width. Thus, a receiver function can be

179 characterized by the following equation in the time domain $(t)$ :

$$
r(t)=f(t) * g(t)
$$

181 where $\mathrm{r}(\mathrm{t})$ is our resulting receiver function, $\mathrm{f}(\mathrm{t})$ is the Green's function (in this case,

182 a spike train of the differences between vertical and radial components) and $g(t)$ is a

183 Gaussian filter whose width is defined by the alpha parameter $\left(\alpha_{g}\right)$, which has the

184 general form: 


$$
g(t)=e^{-\alpha_{g}^{2} t^{2}}
$$

186 This leads to very smooth waveforms that can be defined by the summation of

187 Gaussian pulses centered at different times. In receiver functions derived from the

188 CCP volume, the number of receiver functions incorporated into a bin may vary

189 based on bin size, bin spacing, and the location of the back-projected receiver

190 functions at depth. This has the potential to cause our CCP-derived receiver

191 functions to have unrealistic, sharp changes in amplitude. These unrealistic changes

192 in amplitude are generally small and have a negligible effect on the resulting shear-

193 wave velocity profile when used in a joint inversion. However, we build on the

194 approach of Delph et al. (2015) to smooth out these artifacts at the slight cost of

195 vertical resolution.

196 In this application, we filter our CCP-derived receiver functions with a

197 Gaussian filter $\mathrm{h}(\mathrm{t})$ to dampen unrealistic structures. This makes our new receiver

198 function have the following form:

$$
r_{f i l t}(t)=f(t) * g(t) * h(t)
$$

200 where $\mathrm{h}(\mathrm{t})$ has the same form as $\mathrm{g}(\mathrm{t})$, but a different Gaussian parameter. The

201 convolution of a Gaussian filter with our CCP-derived receiver function changes the

202 "effective" alpha parameter of our resulting receiver function by broadening the

203 Gaussian pulse. Convolution has commutative and associative algebraic properties,

204 thus:

205

$$
r_{f i l t}(t)=[f(t) * g(t)] * h(t)=f(t) *[g(t) * h(t)]
$$

meaning that this multi-step Gaussian filter technique is equivalent to producing a

207 receiver function with a Gaussian pulse width equal to that of produced by the 
208 convolution of two Gaussian pulses with different widths. This relationship allows

209 us to choose a Gaussian filter that will produce a receiver function with a Gaussian

210 pulse width of our choice (which must be lower than the initial Gaussian pulse

211 width of the receiver functions). For example, if we want to obtain a $2.2\left(\alpha_{r f i l t}\right)$

212 Gaussian equivalent receiver function from initial 2.5 $\left(\alpha_{g}\right)$ Gaussian receiver

213 function data, we could solve for the necessary Gaussian filter width parameter with

214 the following equation:

215

$$
\alpha_{h}=\sqrt{\frac{-\left(\alpha_{r f i l t}{ }^{2} \times \alpha_{g}{ }^{2}\right)}{\alpha_{r f i l t}{ }^{2}-\alpha_{g}{ }^{2}}}
$$

216 where the subscripts correspond to Gaussian functions in Eqn. (4). Using this

217 equation, we find that a Gaussian filter with an alpha parameter of $\sim 4.6$ would

218 produce a 2.2 Gaussian equivalent receiver function. These are the values we use in

219 this study. This process, however, does not retain amplitude information, thus we

220 must also perform an amplitude correction for the filtered receiver functions.

\section{$221 \quad$ 2.3.2 Amplitude Correction}

222 The amplitude of a receiver function is linearly related to the Gaussian pulse

223 width and is a function of ray parameter. Thus, we can define the relationship as

224 follows:

225

$$
A(p)=m(p) \times \alpha+b(p)
$$

226 where $\mathrm{A}(p), \mathrm{m}(p)$, and $\mathrm{b}(p)$ is the receiver function amplitude, slope, and $\mathrm{y}-$

227 intercept of the linear trend as a function of ray parameter, and $\alpha$ is the Gaussian

228 pulse width. To calculate the amplitude change between two receiver functions with 
229 a different alpha parameter, we simply divide the amplitude of the receiver function

230 of interest by the amplitude of the receiver function of our data:

231

$$
\frac{A_{1}(p)}{A_{2}(p)}=\frac{m(p) \times \alpha_{1}+b(p)}{m(p) \times \alpha_{2}+b(p)}
$$

232 In this case, $\alpha_{1}$ is a 2.2 and $\alpha_{2}$ is our input data (2.5). We find that, for any ray

233 parameter, the change in the amplitude between two receiver functions of different

234 Gaussian pulse widths is constant (i.e. the relationship between the y-intercept (b)

235 to the slope (m) is constant). This property simplifies this relationship to the

236 following form:

$$
\frac{A_{1}}{A_{2}}=\left(\frac{1}{\alpha_{2}+b / m}\right) \alpha_{1}+\left(\frac{b / m}{\alpha_{2}+b / m}\right) \quad \text { where } b / m=0.226
$$

238 Thus, from the above equation with our Gaussian pulse widths of interest ( $\alpha_{1}=2.2$,

$239 \alpha_{2}=2.5$ ), we find that the amplitude of a 2.2 Gaussian receiver function will have

$24089 \%$ of the amplitude of a 2.5 Gaussian receiver function.

241 In summary, in this altered new approach, we effectively filter our CCP-

242 derived receiver functions with a Gaussian pulse. Convolving a "2.5" receiver

243 function with a Gaussian filter that has an alpha parameter of 4.6 produces a smooth

244 receiver function with an effective alpha parameter of 2.2 (Fig. 2B), thus smoothing

245 across unrealistic artifacts that are the result of the incorporation of different data

246 into a bin at the cost of vertical resolution. Changing the Gaussian pulse width of a

247 receiver function also has an affect on the resulting amplitude of a receiver function,

248 as lower alpha parameters yield much broader Gaussian pulses. The relationship

249 between Gaussian pulse width and amplitude is linear with respect to ray parameter 
251 yields an amplitude that is $89 \%$ of the 2.5 Gaussian receiver function amplitude.

252

253

254

255

256

257

258

259

260

261

262

263

264

265

266

267

268

269

270

271

272

273

274
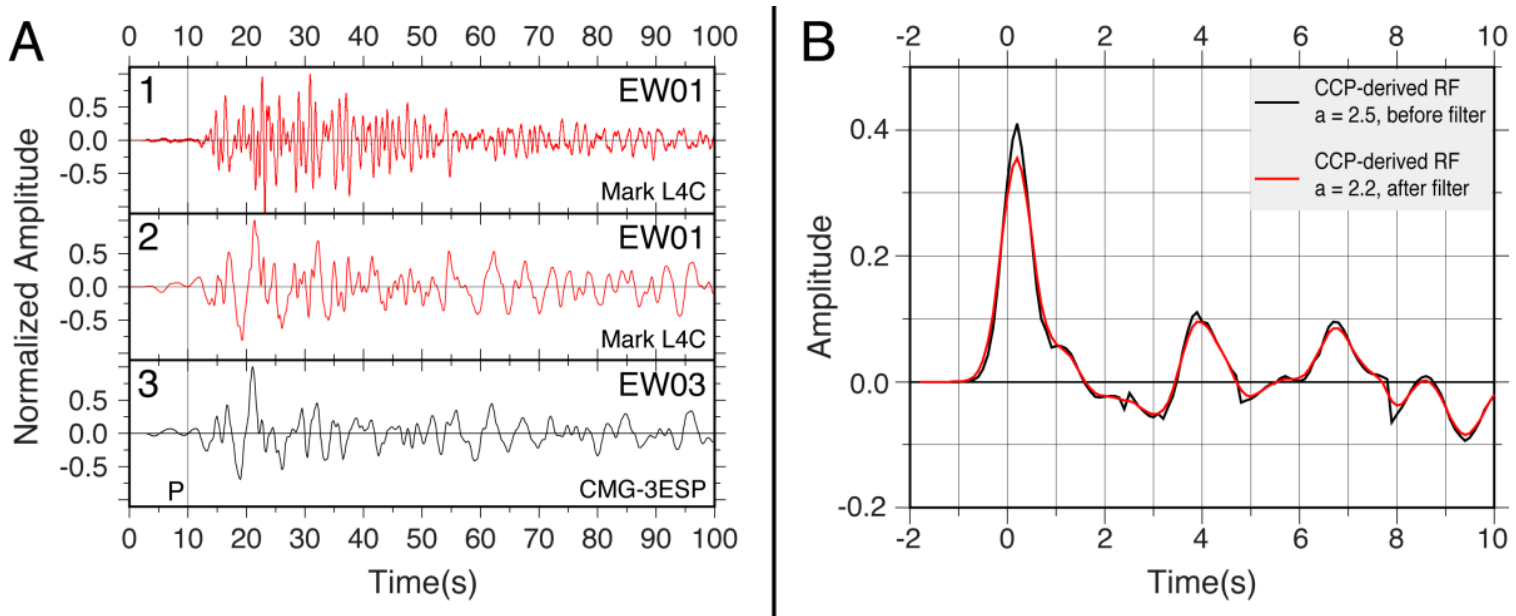

Figure 2: (A) Record of a M 6.5 earthquake that occurred on Sept. 24, 2009 recorded on the vertical component of two seismic stations. Time-series begins 10 seconds before the P-wave arrival. (1) Raw short period seismogram, (2) Short period velocity seismogram after deconvolution of instrument response and filtering, (3) Velocity seismogram from intermediate period sensor after filtering. The similarities of the deconvolved short-period recording and intermediate recording for a teleseismic event indicate that the short period data may be used to compute receiver functions. (B) End-member example of a CCP-derived receiver function profile for a single gridpoint extracted from the CCP volume (black) to the Gaussian-filtered CCP-derived receiver function with amplitude scaling (red). The Gaussian filter mitigates spurious artifacts that can be introduced into the vertical receiver function profile by the incorporation of new receiver function data into a depth bin.

\subsubsection{Joint Inversion}

Surface wave dispersion data and receiver functions are highly complementary datasets, as the shortcoming of each individual dataset is the strength of the other (Julia et al. 2000; Delph et al. 2015). While surface wave dispersion data are good at recovering absolute shear wave velocities as a function of depth, the broad sensitivity kernels (e.g. Fig. 3A) lead to a final model that is highly dependent on an often poorly constrained a priori model, as discontinuities 
275 will not be resolved by the inversion of surface wave dispersion data alone. In

276 contrast, receiver functions are very sensitive to impedance contrasts in the Earth,

277 but have virtually no sensitivity to the absolute velocities on either side of a

278 boundary. By combining these two datasets in a joint inversion approach, we reduce

279 the non-uniqueness of the inverse problem, mitigating the need to have an a priori

280 starting model that is close to the real Earth structure (Delph et al. 2015). In this

281 study, the resulting 2.2 effective Gaussian receiver functions derived from CCP-

282 stacking are paired with the augmented ambient noise-derived dispersion data from

283 Ward et al. (2013) following the procedure outline by Delph et al. (2015) (Fig. 3B).

284 The joint inversion algorithm requires a dataset weighting parameter that defines

285 the relative importance of each dataset to the inversion penalty function, with a

286 value of 0 corresponding to an inversion of only the receiver function data and a

287 value of 1 corresponding to an inversion of only dispersion data (Julia et al. 2000).

288 We choose a weighting parameter of 0.3 , as it leads to a good balance between

289 receiver function fit and dispersion fit. The fit to the dispersion data generally does

290 not improve for weights higher than this value (Delph et al. 2015). The initial model

291 for the joint inversion used in this study consists of a $4.5 \mathrm{~km} / \mathrm{s}$ half-space with $2 \mathrm{~km}$

292 thick layers, as the vertical resolution of a 2.2 Gaussian receiver function is $\sim 2 \mathrm{~km}$.

293 Assuming a very simple velocity model with no a priori information about structure

294 assures that all information in the resulting shear wave velocity model is necessary

295 to satisfy the constraints imposed by the receiver functions and dispersion data. 

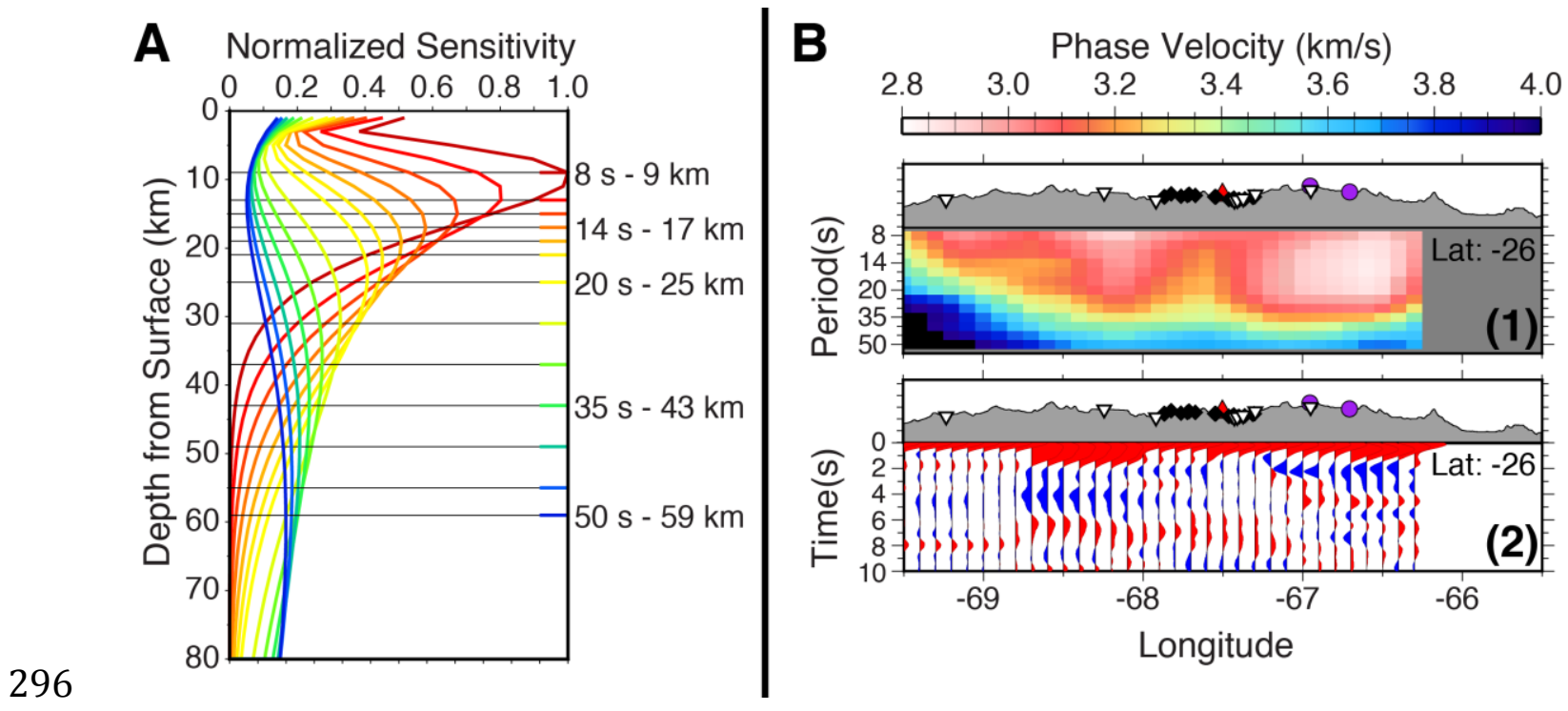

Figure 3: (A) Sensitivity kernels of Rayleigh wave phase velocities to shear wave velocity structure for the periods for a simple half-space (constant velocity) model. (B) Dispersion curves (1) and CCP-derived receiver functions normalized to coherence peak (2) along Latitude -26. Each row of (1) is a phase velocity for a specified period $(8,10,12,14,16,18,20,25,30,35,40,45,50$ seconds) at a tomographic grid-point. These curves are paired with the CCP-derived receiver functions (2) for the joint inversion (resulting shear velocity cross-section shown in Fig. 5E). Receiver functions are normalized to ray parameter of $0.06 \mathrm{~s} / \mathrm{km}$. Purple circles: locations of calderas that sourced ignimbrite eruptions; Red triangles: Holocene volanoes; Inverted triangles: seismic stations; Black diamonds: mafic volcanic samples from Ducea et al. (2013) and Murray et al. (2015).

\section{Results}

311 body beneath the southern Puna Plateau based on a broad low-velocity anomaly

312 extending from the crust into the upper mantle. Further evidence for the existence

313 of the "Southern Puna Magmatic Body" (SPMB; Bianchi et al. 2013) was obtained via

314 earthquake-generated dispersion data (Calixto et al. 2013) and attenuation (Liang et

315 al. 2014), with the largest anomaly lying beneath the Cerro Galan Caldera (Heit et al.

316 2014). In this study, we image the finer-scale crustal structure of the SPMB and

317 observe three separate, tabular slow velocity bodies that together comprise the 
318 SPMB. These bodies are spatially coincident with regions of active arc volcanism in 319 the Lazufre Volcanic Region (Lazufre Anomaly, LA), the southernmost Central 320 Volcanic Zone (Incahuasi Anomaly, IA), and in the interior of the southern Puna 321 plateau beneath the largest ignimbrite center in the region, the Cerro Galan Caldera 322 (Cerro Galan Anomaly, CGA; also imaged by Heit et al. 2014). These bodies are 323 approximately $\sim 10 \mathrm{~km}$ thick, with the top of the slow velocity zones $\sim 16-21 \mathrm{~km}$ 324 below the surface and the slowest seismic velocities at $\sim 20-25 \mathrm{~km}$ depth (Fig. 4, 5). 325 These bodies appear distinctly separate at mid-crustal depths, and have trench326 perpendicular widths of $\sim 50-100 \mathrm{~km}$ based on the $\sim 3.3 \mathrm{~km} / \mathrm{s}$ average crustal shear 327 wave velocity contour (top $50 \mathrm{~km}$ of our model; Fig. 6A). We choose this velocity 328 contour because profiles with average shear wave velocities lower than $\sim 3.3 \mathrm{~km} / \mathrm{s}$ 329 most likely contain partial melt, as it is slower than expected for crystallized, 330 isotropic crustal compositions at mid-crustal depths (Christensen, 1996). 


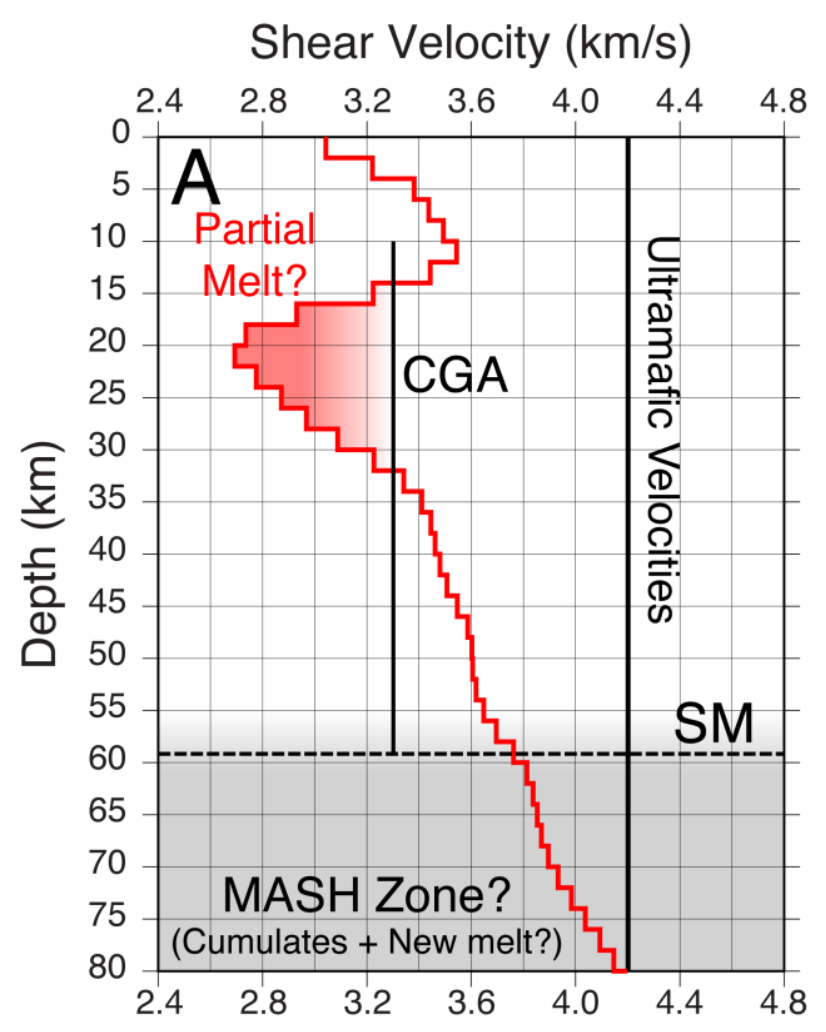

Figure 4: Jointly inverted shear wave velocity profile (A) from dispersion (B) and receiver function (C) data for a gridpoint in the Cerro Galan Caldera (Red Star - Fig. 1). Black points (B) and black line (C) are observed data, while the red lines are predicted by the red model shown in (A). Velocities $<3.3 \mathrm{~km} / \mathrm{s}$ are slow for crustal compositions at mid-crustal depths, and are inferred to contain some amount of partial melt. Shaded red regions in (B) and (C) are responsible for the slow shear wave velocities in (A). The seismic Moho (SM) is thought to be $\sim 59 \mathrm{~km}$ (Heit et al., 2014). Note the slow shear velocities and a very low velocity gradient across the seismic Moho (SM). CGA, Cerro Galan Anomaly; NRMS, Normalized Root Mean Square.

Crustal thickness beneath the southern Puna Plateau vary from $\sim 50-65 \mathrm{~km}$,

344 being thicker in the north and slightly thinner in the plateau interior (Wölbern et al.,

345 2009; Tassara and Echaurren, 2012; Heit et al., 2014). The crust-mantle velocity

346 transition throughout much of the region appears to be rather gradational based on

347 broad low-amplitude receiver function conversions and a lack of an observable

348 inflection in the phase velocity dispersion curves associated with the transition to 
349 higher shear wavespeeds (Fig 3B; Supp. Figs. S3-7) (e.g. Lebedev et al., 2013). After

350 the joint inversion, we observe shear wave velocities that are much slower than

351 expected for typical mantle lithosphere down to the bottom of our model $(<4.1$

$352 \mathrm{~km} / \mathrm{s}$ vs. 4.5 km/s, Kennett and Engdahl, 1991; Figs. 4, 5C-H). Further to the south

353 along the transition from the Puna Plateau to the Sierras Pampeanas, this

354 gradational velocity contrast gives way to a much sharper transition to faster

355 wavespeeds associated with typical mantle lithosphere (Fig. 5H, 6B).

356 We note that our joint inversion results are generally consistent with the

357 receiver function study of Heit et al. (2014) but there are some differences that

358 warrant brief discussion. Heit et al. (2014) identified a strong Moho arrival for much

359 of the region, and also identified a relatively prominent lithosphere-asthenosphere

360 boundary (LAB) at 75 to $80 \mathrm{~km}$ depth in their migrated $\mathrm{P}$ and S-receiver function

361 cross-sections. We believe some of the differences we observe are due to the

362 different processing of the receiver functions, as Heit et al. (2014) processed the

363 data in a manner to emphasize the Moho and LAB arrivals. This included using

364 somewhat lower frequency content (especially for the S-receiver functions) and

365 stacking data in $\sim 100 \mathrm{~km}$ bins along specific profiles. These are reasonable choices

366 to characterize the first-order lithospheric structure for this region. Our processing

367 involved higher frequency data aimed at maximizing resolution within the crust, on

368 which we will focus in the following sections. 


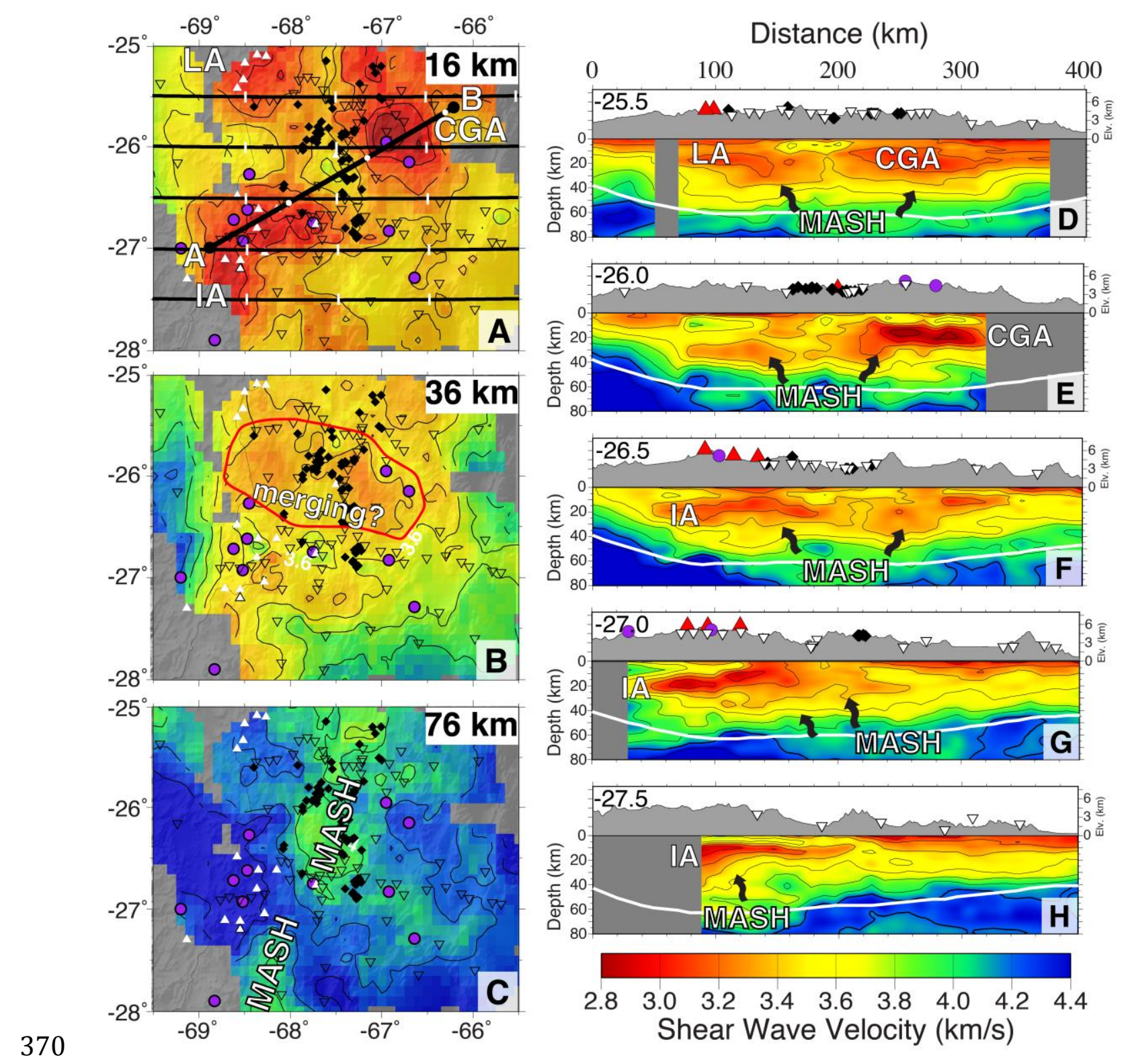

371 Figure 5: Mapslices (A-C) and cross-sections (D-H) relative to sea level through our

372 velocity model. Purple circles: ignimbrite centers; White/Red triangles: Holocene

373 volanoes; Inverted triangles: seismic stations; Black diamonds: mafic volcanic

374 samples from Ducea et al. (2013) and Murray et al. (2015); white lines in cross-

375 sections: Moho depth from Tassara \& Echaurren (2012). Shear velocity contour

376 intervals every $0.2 \mathrm{~km} / \mathrm{s}$. (A) Mid-crustal magma bodies show strong spatial

377 relationship with ignimbrite centers and Holocene volanoes. White dots/bars along

378 cross-section lines demarcate $100 \mathrm{~km}$ intervals. Cross-section A-B shown in Fig. 8.

379 (B) LA and CGA appear to be merging with depth. (C) MASH zones apparent as very

380 slow seismic velocities $(\sim 4 \mathrm{~km} / \mathrm{s})$ at mantle depths $(>60 \mathrm{~km})$ and correlate well

381 with locations of mafic volcanics at the surface (black diamonds). (D-H) Cross-

382 sections at different latitudes through our study area. Locations of cross-sections

383 shown as horizontal lines in (A). Arrows indicate possible magma pathways from 
384 MASH zone to mid-crustal magma reservoirs. CGA, Cerro Galan Anomaly; IA,

385 Incahuasi Anomaly; LA, Lazufre Anomaly

386

\section{Discussion}

\subsection{Crustal Magma Reservoirs}

The trench-perpendicular width of the crustal slow velocity bodies $(\sim 50-100$

390 km, Fig. 6A) makes them the most dominant features of the crust in the southern

391 Puna Plateau, but what do these spatially extensive slow velocity bodies represent?

392 Recent high-resolution seismic images in the northern Puna Plateau (Altiplano-Puna

393 Volcanic Complex, APVC) imaged a similar seismic anomaly, interpreted as a magma

394 reservoir that was feeding the prolific volcanism of the APVC (Ward et al. 2014).

395 Based on the spatial correlation of these slow velocity bodies with surficial

396 volcanism both in the arc and backarc, we also interpret these bodies to represent

397 extensive mid-crustal magma reservoirs (or more appropriately, mush bodies) that

398 are feeding volcanism in the southern Puna Plateau.
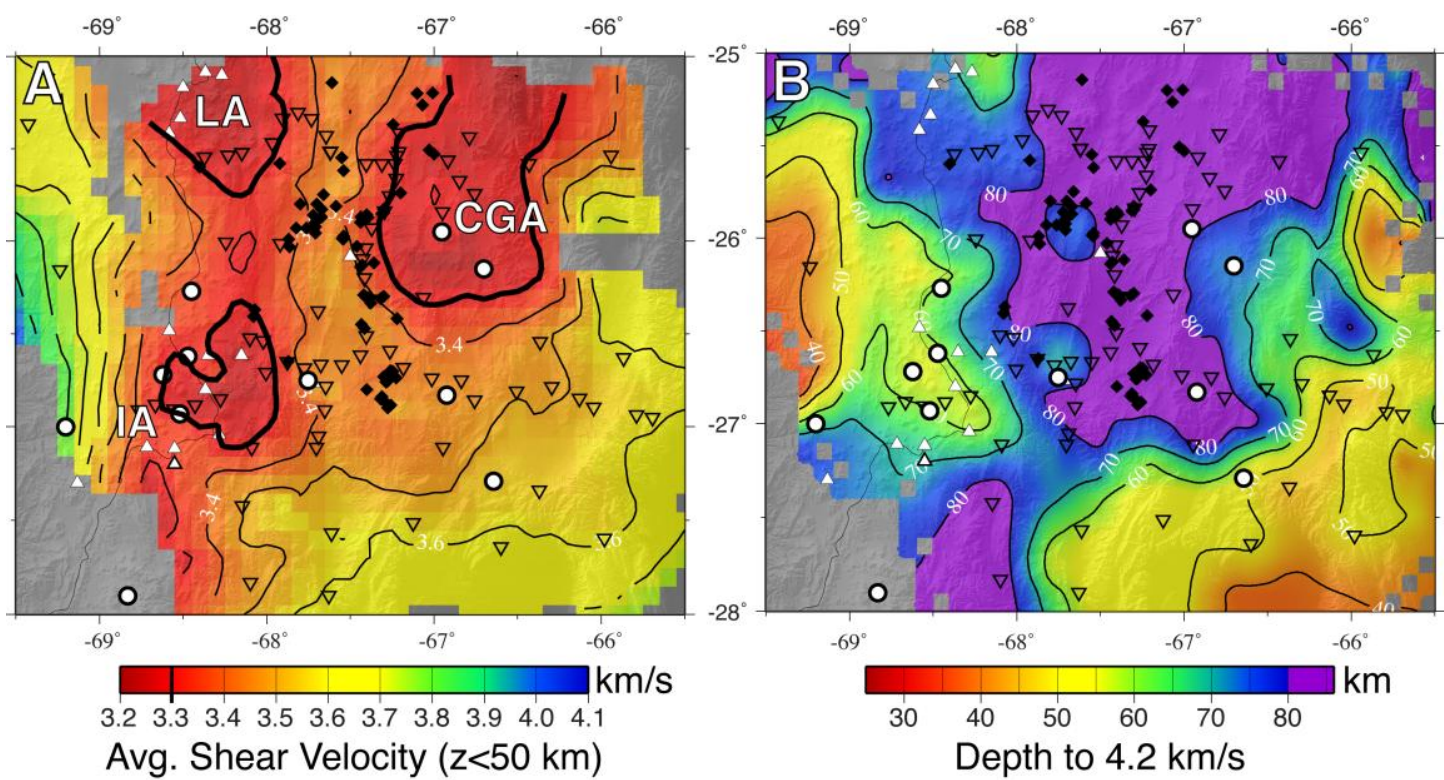

Avg. Shear Velocity $(\mathrm{z}<50 \mathrm{~km})$

Depth to $4.2 \mathrm{~km} / \mathrm{s}$

400 Figure 6: (A) Average shear-wave velocity in the top $50 \mathrm{~km}$ of our velocity model.

401 Slow seismic velocities correspond well with the active Central Volcanic Zone (white 
402 triangle) and the Cerro Galan Caldera. CGA: Cerro Galan Anomaly; IA: Incahuasi

403 Anomaly; LA: Lazufre Anomaly. (B) Depth to the $4.2 \mathrm{~km} / \mathrm{s}$ shear-wave velocity in

404 our model (relative to sea level). Purple region indicates where a velocity of 4.2

$405 \mathrm{~km} / \mathrm{s}$ was not reached by the bottom of our seismic velocity model, and is indicative

406 of regions that have undergone delamination. Data is filtered using a $0.3 \times 0.3$ degree

407 boxcar filter to show only long-wavelength features. Inverted triangle are seismic

408 stations used in this study, white circles are ignimbrite centers, white upright

409 triangles are Holocene volcanoes, and black diamonds are mafic volcanic samples

410 from Murray et al. (2015) that approximately delineates recent ( $<8 \mathrm{Ma}$ ) mafic

411 volcanism in the southern Puna.

412

413 It is unlikely that these anomalies represent a single intrusion at depth, as an

414 active magmatic arc that operates at any one time is generally much smaller in

415 lateral extent ( $\sim 35 \mathrm{~km}$; Ducea et al., $2015 \mathrm{~b})$ than our slow velocity bodies, which are

416 comparable to the width of the entire Sierra Nevada composite batholith $(\sim 80-120$

$417 \mathrm{~km})$. However, the thermal history and longevity of magmatic arcs is an ongoing

418 research problem (Gelman et al., 2013), and some of the spatial extent of the slow

419 velocity bodies could be attributed to thermal effects of recently intruded, hot

420 material on seismic velocities. Also, plutons exposed in the North American

421 Cordillera generally have crystallization depths that are shallower than the depths

422 to the top of our slow velocity anomalies (Chapman et al., 2012), and other

423 seismically imaged magma bodies are generally smaller and shallower as well

424 (Seccia et al., 2011; Kiser et al., 2016). Hence, we suspect that the zones of slow

425 velocity imaged in this study may be sourcing similar shallow magma bodies that

426 may be too small to resolve using this approach, such as the one imaged beneath the

427 Lazufre region by Spica et al. (2015). Deeper exposed sections in the Sierra Nevada

428 batholith and Famatinian arc immediately south of the Puna Plateau indicate that

429 the dominant fabrics of arc rocks undergo a transition from vertical igneous- 
430 metamorphic fabrics (e.g. stocks) to planar fabrics at $\sim 20 \mathrm{~km}$ depth, in general

431 agreement with the top of the LVZs in the southern Puna Plateau (Saleeby et al.,

432 2003; Ducea et al., 2015a; Ducea et al., 2015c). Thus, the slow velocity bodies we

433 image may represent zones of partially molten material that have stalled at this

434 transition.

$435 \quad$ 4.2 The Cerro Galan Magma Body

436 The Cerro Galan Anomaly (CGA) is the largest slow velocity anomaly imaged

437 in this study and ranges in depth from $12-24 \mathrm{~km}$ below sea level (BSL) or $16-28$

$438 \mathrm{~km}$ below surface, with an estimated volume of $\sim 22,000 \mathrm{~km}^{3}$ based on the $2.9 \mathrm{~km} / \mathrm{s}$

439 velocity contour (a rather conservative estimate for regions containing partial melt,

440 see Ward et al., 2014). This anomaly appears to be a robust feature of the crust, as it

441 has been imaged by multiple other techniques at varying resolutions (Bianchi et al.,

442 2013; Calixto et al., 2013; Heit et al., 2014; Liang et al., 2014). The depth of the CGA

443 in this study shows remarkable consistency with geobarometric measurements of

444 Cerro Galan-sourced ignimbrites that indicate magmatic hybridization takes place

$445 \sim 16 \mathrm{~km}$ BSL (20 km below surface; Kay et al., 2011) (Fig. 4). Approximating this

446 slow velocity body as a oblate spheroid, it has a horizontal to vertical aspect ratio of

$447 \sim 4.5: 1$, slightly less than the $\sim 10: 1$ ratio of the slow velocity body associated with

448 the Altiplano-Puna Volcanic Complex (Ward et al., 2014) and on the smaller end of

449 other imaged magma reservoirs which tend have a range between 5-10:1

450 (Bachmann and Bergantz, 2008).

451 In plateaus, the underthrusting and burial of upper crustal igneous rocks and

452 sediments due to foreland thrusting creates an environment that is fertile for 
453 anatexis (Decelles et al., 2009) (i.e. the formation of migmatites), as residence time

454 in the mid-crust is extended due to low erosion rates in plateau interiors. A possible

455 exposed analog for the CGA is found in the Angel Lake metamorphic suite located in

456 the Ruby Mountains (Nevada, USA). This metamorphic suite is a 20-30 km exposure

457 of the Cretaceous-Eocene Nevadaplano crust (Howard et al., 2011). It contains a

458 large proportion $(>50 \%)$ of in-situ or short-traveled silicic melts derived from the

459 partial melting of local Precambrian and Paleozoic rocks (migmatites) intermixed

460 with sills of Eocene mafic to intermediate intrusives that were generated near the

461 base of the crust. In the context of the southern Puna Plateau, the periodic intrusion

462 of mafic-intermediate melts into a mid-crustal migmatized zone as a result of the

463 steepening of the subduction angle (and possibly delamination) could act as

464 rejuvenation events to the magma reservoir, prolonging its state as a partially

465 crystallized mush zone and increasing its lateral extent (e.g. Cao et al. 2016). The

466 influx of this new, hot material from below could have resulted in the eruption of the

467 ignimbrites associated with the Cerro Galan Caldera ranging in age from $~ 6-2 \mathrm{Ma}$.

$468 \quad$ Following the approach of Ward et al. (2014), estimates of plutonic to

469 volcanic (P:V) ratio can be calculated based on the cumulative erupted volume of the

470 Cerro Galan Caldera ( $\sim 1300 \mathrm{~km}^{3}$; Kay et al., 2011$)$, and the percentage of material

471 encompassed by the $2.9 \mathrm{~km} / \mathrm{s}$ contour that is considered to be plutonic (Fig. 7A).

472 Considering an estimate that $50 \%$ of the total volume of the slow velocity body is

473 plutonic (i.e. in-situ melt and igneous rocks that are coeval with volcanism) based on

474 observations from the Ruby Mountains leads to a P:V ratio of $\sim 8: 1$. This is a very

475 conservative estimate for the P:V ratio since we are neglecting melt that was most 
476 likely introduced via subduction processes. Also, if a higher seismic velocity is used

477 to estimate the volume of plutonic material (possibly up to $\sim 3.3 \mathrm{~km} / \mathrm{s}$ ), this ratio

478 increases to values $>10: 1$, which is larger than often cited ranges for P:V ratios

479 ( 5:1; White et al., 2006). At velocities $>3 \mathrm{~km} / \mathrm{s}$, the volume of the CGA no longer

480 closes in our model, which hinders the meaingful estimation of P:V ratios if a higher

481 velocity is assumed to contain partial melt. However, the range of P:V ratios that we

482 obtain in this study accompanied by recent estimates of $\sim 25-35: 1$ in the APVC

483 (Ward et al., 2014) and the >10:1 in the San Juan Batholith (Lipman and Bachmann,

4842015 ) indicate that much higher P:V ratios exist than previously expected. The

485 interactions between the host rock and these large volumes of intruded material

486 from the mantle may be a significant contributor to the formation of more felsic

487 continental compositions, especially in long-lived systems like the North and South

488 American Cordillera. Estimating P:V ratios for the frontal arc (IA and LA) is not

489 possible at the present time because: 1) accurate estimates of the volume of erupted

490 volcanic material in the frontal arc do not exist at this time (it is hard to measure the

491 depth extent of volcanic material below the surface in long-lived arcs), 2) the shear

492 wave velocity anomalies are not fully enclosed by our current results (e.g. Fig. 5A).

493 Using the relationship between shear velocity and melt fraction of Takei

494 (2002) and the contiguity-porosity relationships from Yoshino et al. (2005) for a

495 felsic system, we can estimate the percentage of partial melt in the CGA. The

496 relationship between melt fraction and shear wave velocity is dependent on the

497 contiguity of the melt in a crystal matrix (a function of dihedral angle), the melt

498 fraction (or porosity) of the partially molten region, and the densities of both the 
crystalline rock and its compositional equivalent for melt (Takei, 2002). The

500 dihedral angle of a crystal mush (crystals + melt) is largely dependent on the

501 composition of the melting material, and was experimentally derived for various

502 compositions by Yoshino et al. (2005). The lowest shear wave velocity we obtain in

503 the CGA is $\sim 2.7 \mathrm{~km} / \mathrm{s}$ : a $25 \%$ decrease in shear velocity assuming that a

504 compositionally similar, crystalline rock would have a shear velocity of a

505 granite/granodiorite $(\sim 3.6 \mathrm{~km} / \mathrm{s})$ (Fig. 7B). This decrease in seismic velocity

506 indicates a maximum melt percentage of $\sim 22 \%$ in the CGA. The rheology of a silicate

507 melt is thought to increase rapidly after the melt percentage decreases below $\sim 60 \%$,

508 inhibiting the ability of the partially molten body to internally convect (Marsh, 1981;

509 Lejeune and Richet, 1995). Thus, barring a rejuvenation event by melt from below,

510 the CGA is unlikely to represent an eruptible body.
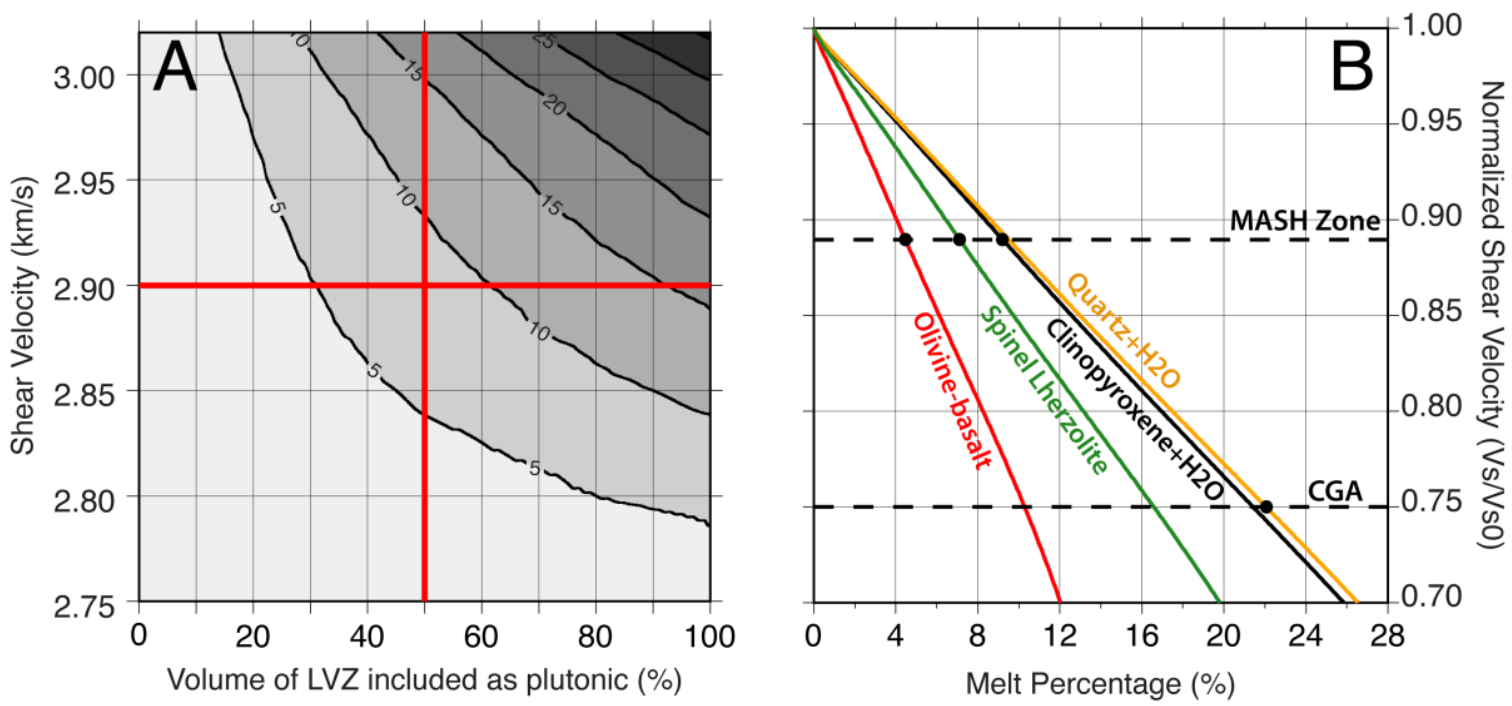

512 Figure 7: (A) P:V ratios of the CGA depending on shear velocity used to constrain

513 the volume of partially molten material and the percentage of that material which is

514 considered plutonic. In order to make a conservative estimate of the P:V ratio for the

515 CGA, we use the $2.9 \mathrm{~km} / \mathrm{s}$ shear velocity contour and $50 \%$ plutonic material as

516 observed in the migmatites in the Ruby Mountains (Howard et al., 2011) to obtain a

$517 \quad \mathrm{P}: \mathrm{V}$ ratio of 8:1. This estimate does not include plutonic material introduced via

518 subduction processes. (B) Normalized shear wave velocity plotted against melt 
519 percentage from the relationships of Yoshino et al. (2005) and Takei (2002). For the

520 CGA, the maximum melt percentage is $\sim 22 \%$ (assuming a Vs of $3.6 \mathrm{~km} / \mathrm{s}$ should the

521 LVZ crystallize completely). In the MASH zone, melt percentage ranges between $\sim 4$

$522-9 \%$ depending on bulk composition and a Vs of $4.5 \mathrm{~km} / \mathrm{s}$ should the slow velocity

523 material crystallize completely.

524

525 4.3 Melt at the Crust-Mantle Transition: Seismic Imaging of a MASH Zone

526 Beneath volcanics arcs lies the melting, assimilation, storage, and

527 homogenization (MASH) zone (Hildreth and Moorbath, 1988) located at the crust-

528 mantle transition. In this zone, the lower densities associated with crustal material

529 causes slightly denser mantle-derived melts to stall, mix with lower crustal material,

530 and undergo density differentiation. From this level, less dense (and more felsic)

531 melts can rise to shallower depths in the crust, leaving behind dense "cumulates" of

532 mafic-ultramafic material that either remain near the crust-mantle transition or

533 gravitationally sink back into the mantle (Hildreth and Moorbath, 1988; Saleeby et

534 al., 2003). The MASH zone is particularly difficult to image due to its dominantly

535 mafic-ultramafic composition with small amounts of partial melt (Hildreth and

536 Moorbath, 1988), as partially molten mafic material will have seismic velocities

537 similar to that of both a crystallized felsic-intermediate lower crust as well as warm

538 upper mantle (asthenospheric) material.

539 The presence of a felsic lower crust is unlikely based on geochemical

540 constraints given by basaltic samples at the surface, which indicate a lower crust of

541 dominantly pyroxenitic compositions (Ducea et al., 2013; Murray et al., 2015). Also,

542 a gradational crust-mantle transition at $\sim 50-65 \mathrm{~km}$ in the southern Puna Plateau is

543 consistent with more mafic lower crustal compositions (Tassara and Echaurren,

544 2012; Heit et al., 2014). Based on the very slow seismic velocities imaged beneath 
545 the central Puna Plateau at mantle depths $(<4.1 \mathrm{~km} / \mathrm{s}$ vs. $4.5 \mathrm{~km} / \mathrm{s}$ for typical

546 mantle; Kennett and Engdahl, 1991), we infer that these slow seismic velocities

547 represent the presence of partially molten mafic-ultramafic compositions at and

548 near the crust-mantle transition (i.e. MASH zone) (Fig. 4, Fig. 5D-H). Assuming an

549 overall ultramafic bulk composition in the lower crust (Kay et al., 1994; Ducea et al.,

550 2013), this partially molten zone is estimated to contain $\sim 4-9 \%$ partial melt (Takei,

551 2002; Yoshino et al., 2005) (Fig. 7B).

552 We use the shallowest depth where our velocity model reaches $4.2 \mathrm{~km} / \mathrm{s}$ to

553 indicate the transition across the seismic Moho, as generally only crystallized

554 ultramafic rocks will have wavespeeds greater or equal to this value (e.g.

555 hornblendite, pyroxenite, peridotite; Christensen, 1996). Similar to the western

556 United States, significant removal of dense lower crust and mantle lithosphere is

557 thought to have occurred through the process of lithospheric foundering (Ducea and

558 Saleeby, 1998; Zandt et al., 2004; Erdman et al., 2016) based on teleseismic

559 tomography (Scire et al., 2014; Beck et al., 2015), structural data (Schoenbohm and

560 Carrapa, 2015), and the isotopic signatures of mafic volcanism in the region (Kay et

561 al., 1994; Ducea et al., 2013; Murray et al., 2015) (Fig 6B). Regions where velocities

562 of $4.2 \mathrm{~km} / \mathrm{s}$ are not reached by $80 \mathrm{~km}$ may represent areas that have undergone

563 delamination, which has allowed for partial melt to accumulate due to the influx of

564 asthenosphere and associated decompression melting (purple region, Fig. 6B).

565 Interestingly, the few mafic volcanic deposits in the Puna Plateau spatially correlate

566 with the slowest seismic velocities in the uppermost mantle and anti-correlate with

567 inferred mid-crustal magmatic reservoirs (black diamonds, Fig. 6A). Our preferred 
568 explanation is that the seismically faster material that separates the magma

569 reservoirs is crystalline crust that does not impede the low viscosity mafic melts

570 from propagating to the surface. However, these melts can only make it to the

571 surface where they are not captured by magma reservoirs in the mid-crust (Figs. 5A,

$5726 \mathrm{~A}$ ). If these rising basaltic melts intersect a magma reservoir, they are captured and

573 incorporated into the magma reservoir, extending its lifetime. This could also lead to

574 a rejuvenation and resulting eruption if the influx is high enough.

575 Should delamination have occurred in this region, it is unlikely that

576 significant mantle lithosphere underlies the southern Puna Plateau. However, a

577 negative velocity contrast is observed in S-receiver functions at $\sim 80 \mathrm{~km}$ that has

578 been interpreted as the lithosphere-asthenosphere boundary (Heit et al. 2014).

579 We cannot verify the existence of a decrease in velocity at this depth with our

580 results (maximum depth $=80 \mathrm{~km}$ ), but this interpreted LAB should be located near

581 the base of the MASH zone.

582 4.4 The Evolution of the Southern Puna Magmatic System

$583 \quad$ The evolution of the southern Puna Plateau based on Kay and Coira (2009)

584 and these new seismic images is shown in Fig. 8. Initially, arc magmatism is

585 generated by "typical" subduction zone processes (e.g. wet melting above the mantle

586 wedge), leading to the creation of a hot and gradational crust-mantle transition zone

587 (MASH zone) beneath the rheologically weak crust of the active frontal arc. The

588 subducting slab then shallowed, possibly related to the southward migration of the

589 Juan Fernandez ridge (Yáñez et al., 2001) leading to an eastward migration of the

590 frontal arc (Fig. 8A). At the same time, underthrusting of the foreland beneath the 
591 eastern margin of the Puna Plateau increased (Babeyko and Sobolev, 2005), which

592 introduced sedimentary material into the mid-crust leading to the formation of a

593 migmatized (partially molten) zone. The shallowing of the subducting slab may have

594 also led to hydration of the mantle wedge, similar to what is seen below the Sierras

595 Pampeanas today (Porter et al., 2012). During this time, crustal thickening, tectonic

596 shortening, the build-up of cumulates in the lower crust due to mantle addition, and

597 underthrusting of foreland sediments results in pyroxenitic lowermost crustal

598 compositions, which has densities similar to or greater than that of the underlying

599 asthenosphere (DeCelles et al., 2009; Ducea et al., 2013). As the slab rolls back and

600 returns to a more steep subduction angle ( $\sim 30$ degrees), room is created for the

601 dense and gravitationally unstable lower crust to founder as Rayleigh-Taylor

602 instabilities (Elkins-Tanton, 2005; Schoenbohm and Carrapa, 2015) (Fig. 8B).

603 Foundering then drives upward asthenospheric flow into the hydrated mantle

604 beneath the plateau, leading to an increased flux of mantle-derived melting on either

605 side of the foundering body (Elkins-Tanton, 2005; Elkins-Tanton, 2007). This results

606 in the formation of a backarc MASH zone that sourced the recent eruptions of

607 ignimbrites related to the Cerro Galan Caldera. As the foundering body is removed,

608 these separate MASH zones assimilate into one large MASH zone that we image as a

609 central zone of slow velocities beneath the southern Puna Plateau. This

610 amalgamated MASH zone now feeds both the arc volcanism as well as the magma

611 reservoir associated with the CGA (Fig. 6B, 7C). Between the frontal arc and the CGA,

612 relatively fast $(\sim 3.6 \mathrm{~km} / \mathrm{s})$ average shear wave velocities are observed (Fig. 8D) that

613 appear to separate the magma reservoirs of the frontal arc and backarc. This zone 
614 may act as a rheological barrier to rising silicic melts, possibly diverting them along

615 the thermally weakened pathways of long-lived magma ascent, as expected from

616 modeling of magmatic systems (Cao et al., 2016). This zone is relatively strong

617 because it has not been exposed to the fluids and high temperatures associated with

618 magma ascent nearly as long as the arc and backarc regions, as the delaminating

619 body may have insulated it from rising asthenosphere and associated melt (Elkins-

620 Tanton, 2007) (Fig. 8B). After the delaminating body is removed, lower crustal

621 pyroxenites may undergo small-scale delamination, melting as they sink into the

622 mantle. This melt is then re-incorporated into the MASH zone (Elkins-Tanton,

623 2007), leading to the isotopic characteristics of the mafic deposits seen at the

624 surface today (Kay et al., 1994; Ducea et al., 2013; Murray et al., 2015). 

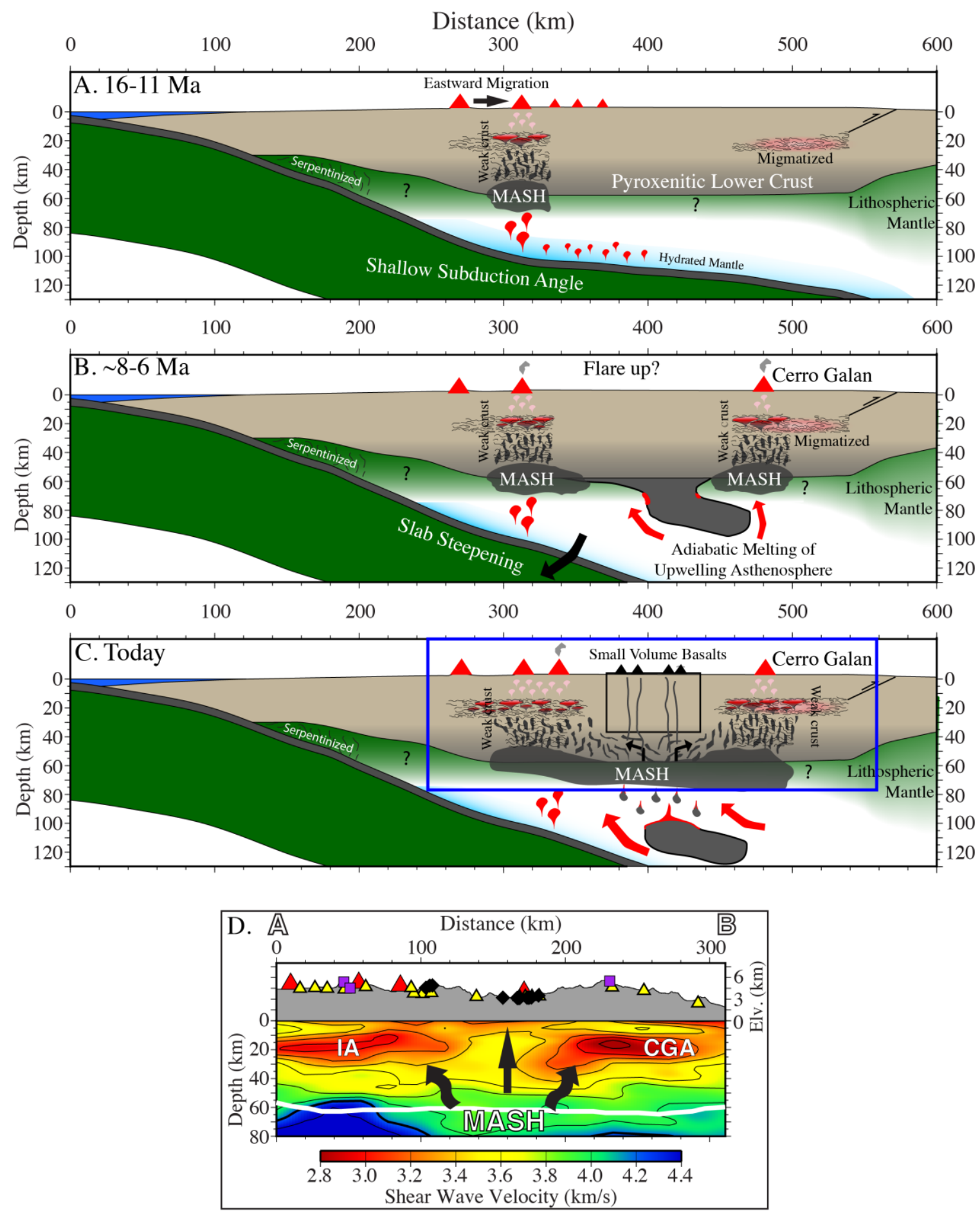

626 Figure 8: Conceptual evolutionary diagram of the magmatic system in the southern

627 Puna Plateau. (A) A shallowing of the angle of subduction leads to an eastward

628 migration of the frontal arc, and underthrusting of foreland material beneath the

629 eastern Puna Plateau to mid-crustal depths leads to anatexis and the formation of a

630 migmatite zone. (B) Initial stages of large-scale delamination of the uppermost

631 mantle lithosphere and lower crust. Adiabatic melting of the inflowing

632 asthenosphere leads to the creation of MASH zone in backarc distinct from the 
633 frontal arc MASH zone. Local melting of the pyroxenitic lower crust is incorporated

634 in the MASH zone, which is reflected in the geochemical signature of the mafic

635 deposits at the surface. (C) After the delaminating body is removed, arc and backarc

636 MASH zones merge into one centralized MASH zone, while small-scale pyroxenitic

637 drips are partially melted as they fall into the mantle. Influx of magmatic material

638 into the mid-crust follows rheologically weak, long-lived zones of magma ascent

639 from Stage A and B. Blue square shows approximate cross-sectional area shown in

640 D. (D). Cross-section through our velocity model along A-B shown in Fig. 5A. Depths

641 relative to sea level. White line, Moho depth from Tassara \& Echaurren (2012); CGA,

642 Cerro Galan Anomaly; IA, Incahuasi Anomaly.

643

\section{5. Conclusions}

645 In this paper, we jointly invert CCP-derived receiver functions and dispersion

646 data from ambient noise tomography to image a lithospheric-scale magma plumbing

647 system beneath the volcanically active Southern Puna Plateau. Three separate slow

$648(<3.0 \mathrm{~km} / \mathrm{s})$ velocity bodies, which we interpret to represent magma reservoirs, are

649 imaged in the mid-crust beneath the active frontal arc of the Lazufre volcanic field

650 and the southernmost Central Volcanic Zone, as well as beneath the Cerro Galan

651 Caldera. These bodies have vertical and lateral extents of $\sim 10 \mathrm{~km}$ and up to $75 \mathrm{~km}$,

652 while the top of these zones occurs at $\sim 16-21 \mathrm{~km}$ below the surface. The Cerro

653 Galan Anomaly is the slowest anomaly in this study and represents a magma

654 reservoir beneath the Cerro Galan Caldera, which erupted $\sim 1300 \mathrm{~km}^{3}$ of material

655 from $\sim 6-2 \mathrm{Ma}$. When compared to the erupted volume, this $22,000 \mathrm{~km}^{3}$ slow

656 velocity body represents a plutonic-volcanic ratio of at least 8:1 and contains a

657 maximum of $22 \%$ melt. Eruptions may have been driven by the influx of new

658 mantle-derived melt from an underlying MASH zone into this partially molten mid-

659 crustal zone. This MASH zone is imaged as a broad, N-S trending slow velocity zone

$660(<4.1 \mathrm{~km} / \mathrm{s})$ at mantle depths with $\sim 4-9 \%$ melt, and we interpret the spatial extent 
661 of this MASH zone to approximately delimit the areal extent of lithospheric

662 delamination beneath the southern Puna Plateau. Felsic melts derived from this

663 MASH zone rise into the crust and are diverted into the frontal arc and backarc

664 magma reservoirs. This lithospheric-scale magma system has significant

665 implications for the creation and evolution of continental lithosphere in Cordilleran

666 systems.

667

668 Acknowledgements

669 This research was funded as part of the Multi-scale Imaging of Modern Orogenic

670 South America (MIMOSA; NSF Award \#1415914). Special thanks to the GFZ and Eric

671 Sandvol, Suzanne M. Kay, and Larry Brown for collecting this dataset as part of NSF

672 Awards \#0538245 and \#0538112. The facilities of IRIS Data Services, and

673 specifically the IRIS Data Management Center, were used for access to waveforms

674 and related metadata used in this study. IRIS Data Services are funded through the

675 Seismological Facilities for the Advancement of Geoscience and EarthScope (SAGE)

676 Proposal of the National Science Foundation under Cooperative Agreement EAR-

677 1261681. Data for the PUDEL experiment was obtained from the GFZ

678 (http://geofon.gfz-potsdam.de).

\section{REFERENCES}

680 Babeyko, A.Y., and Sobolev, S. V., 2005, Quantifying different modes of the late

681 Cenozoic shortening in the central Andes: Geology, v. 33, no. 8, p. 621-624, doi:

$682 \quad 10.1130 / G 21126.1$

683 Bachmann, O., and Bergantz, G., 2008, The magma reservoirs that feed 
supereruptions: Elements, v. 4, no. 1, p. 17-21, doi: 10.2113/GSELEMENTS.4.1.17.

686 Barmin, M.P., Ritzwoller, M.H., and Levshin, A.L., 2001, A fast and reliable method for 687 surface wave tomography: Pure and Applied Geophysics, v. 158, no. 8, p. 13511375, doi: http://dx.doi.org/10.1007/PL00001225.

Beck, S.L., Zandt, G., Ward, K.M., Scire, A., Beck, S.L., and Ward, K.M., 2015, Multiple styles and scales of lithospheric foundering beneath the Puna Plateau, central

Best, M.G., Barr, D.L., Christiansen, E.H., Gromme, S., Deino, A.L., and Tingey, D.G., Andes: GSA memoir 212, v. 1212, no. 3, p. 43-60, doi: 10.1130/2015.1212(03). 2009, The Great Basin Altiplano during the middle Cenozoic ignimbrite flareup:

696 Best, M.G., Christiansen, E.H., de Silva, S., and Lipman, P.W., 2016, Slab-rollback ignimbrite flareups in the southern Great Basin and other Cenozoic American arcs: A distinct style of arc volcanism: Geosphere, v. 12, no. 4, p. GES01285.1,

700 Bianchi, M., Heit, B., Jakovlev, A., Yuan, X., Kay, S.M., Sandvol, E., Alonso, R.N., Coira, 701 B., Brown, L., Kind, R., and Comte, D., 2013, Teleseismic tomography of the 702 southern Puna plateau in Argentina and adjacent regions: Tectonophysics, v. $703 \quad$ 586, p. 65-83, doi: 10.1016/j.tecto.2012.11.016.

704 Calixto, F.J., Sandvol, E., Kay, S., Mulcahy, P., Heit, B., Yuan, X., Coira, B., Comte, D., and 705 Alvarado, P., 2013, Velocity structure beneath the southern Puna plateau: 706 Evidence for delamination: Geochemistry, Geophysics, Geosystems, v. 14, no. 
10, p. 4292-4305, doi: 10.1002/ggge.20266.

708 Cao, W., Kaus, B.J.P., and Paterson, S., 2016, Intrusion of granitic magma into the 709 continental crust facilitated by magma pulsing and dike-diapir interactions:

$710 \quad$ Numerical simulations: Tectonics, p. 1575-1594, doi: 10.1002/2015TC004076.

711 Chapman, A.D., Saleeby, J.B., Wood, D.J., Piasecki, A., Kidder, S., Ducea, M.N., and

712 Farley, K.A., 2012, Late Cretaceous gravitational collapse of the southern Sierra

713 Nevada batholith, California: Geosphere, v. 8, no. 2, p. 314, doi:

$714 \quad 10.1130 /$ GES00740.1.

715 Christensen, N.I., 1996, Poisson's ratio and crustal seismology: Journal of

716 Geophysical Research, v. 101, no. B2, p. 3139, doi: 10.1029/95JB03446.

717 Comeau, M.J., Unsworth, M.J., Ticona, F., and Sunagua, M., 2015, Magnetotelluric

718 images of magma distribution beneath Volcán Uturuncu, Bolivia: Implications

719 for magma dynamics: Geology, v. 43, no. 3, p. 243-246, doi: 10.1130/G36258.1.

720 DeCelles, P.G., Ducea, M.N., Kapp, P., and Zandt, G., 2009, Cyclicity in Cordilleran

721 orogenic systems: Nature Geoscience, v. 2, no. 4, p. 251-257, doi:

$722 \quad 10.1038 /$ ngeo469.

723 Delph, J.R., Zandt, G., and Beck, S.L., 2015, A new approach to obtaining a 3D shear

724 wave velocity model of the crust and upper mantle: An application to eastern

725 Turkey: Tectonophysics, v. 665, p. 92-100, doi: 10.1016/j.tecto.2015.09.031.

726 Ducea, M.N., Otamendi, J.E., Bergantz, G.W., Jianu, D., and Petrescu, L., 2015a, The

727 Ordovician Famatinian-Puna arc: GSA Memoir, v. 212, no. JANUARY 2015, p.

$728 \quad$ 125-138, doi: $10.1130 / 2015.1212(07)$.

729 Ducea, M.N., Paterson, S.R., and DeCelles, P.G., 2015b, High-volume magmatic events 
in subduction systems: Elements, v. 11, no. 2, p. 99-104, doi: 10.2113/gselements.11.2.99.

732 Ducea, M., and Saleeby, J., 1998, A Case for Delamination of the Deep Batholithic 733 Crust beneath the Sierra Nevada, California: International Geology Review, v. 734 40, no. 1, p. 78-93, doi: 10.1080/00206819809465199.

735 Ducea, M.N., Saleeby, J.B., and Bergantz, G., 2015c, The Architecture, Chemistry, and

736 Evolution of Continental Magmatic Arcs: Annual Review of Earth and Planetary 737 Sciences, v. 43, no. 1, p. 299-333, doi: 10.1146/annurev-earth-060614-105049.

738 Ducea, M.N., Seclaman, A.C., Murray, K.E., Jianu, D., and Schoenbohm, L.M., 2013, 739 Mantle-drip magmatism beneath the Altiplano-Puna plateau, central Andes:

$740 \quad$ Geology, v. 41, no. 8, p. 915-918, doi: 10.1130/G34509.1.

741 Elkins-Tanton, L.T., 2007, Continental magmatism, volatile recycling, and a

742 heterogeneous mantle caused by lithospheric gravitational instabilities: Journal 743 of Geophysical Research: Solid Earth, v. 112, no. 3, p. 1-13, doi:

$744 \quad 10.1029 / 2005 J B 004072$.

745 Elkins-Tanton, L.T., 2005, Continental magmatism caused by lithospheric

746 delamination: Geological Society of America Special Papers, v. 80301, no. 303, p. $747 \quad 449-461$, doi: $10.1130 / 2005.2388(27)$.

748 Erdman, M.E., Lee, C.T.A., Levander, A., and Jiang, H., 2016, Role of arc magmatism 749 and lower crustal foundering in controlling elevation history of the $750 \quad$ Nevadaplano and Colorado Plateau: A case study of pyroxenitic lower crust 751 from central Arizona, USA: Earth and Planetary Science Letters, v. 439, p. 48$752 \quad$ 57, doi: 10.1016/j.epsl.2016.01.032. 
753 Freymuth, H., Brandmeier, M., and Wörner, G., 2015, The origin and crust/mantle mass balance of Central Andean ignimbrite magmatism constrained by oxygen and strontium isotopes and erupted volumes: Contributions to Mineralogy and

757 Gelman, S.E., Gutiérrez, F.J., and Bachmann, O., 2013, On the longevity of large upper Petrology, v. 169, no. 6, p. 58, doi: 10.1007/s00410-015-1152-5.

760 Heit, B., Yuan, X., Kind, R., and Günter, A., 2007, Lithospheric Dynamics in the

761 Southernmost Andean Plateau, Deutsches GeoForschungZentrum GFZ, 762

763 Heit, B., Bianchi, M., Yuan, X., Kay, S.M., Sandvol, E., Kumar, P., Kind, R., Alonso, R.N., 764 Brown, L.D., and Comte, D., 2014, Structure of the crust and the lithosphere 765 beneath the southern Puna plateau from teleseismic receiver functions: Earth 766 and Planetary Science Letters, v. 385, p. 1-11, doi: 10.1016/j.epsl.2013.10.017.

767 Hildreth, W., and Moorbath, S., 1988, Crustal contribution to arc magmatism in the 768 Andes of Central Chile: Contributions to Mineralogy and Petrology, v. 98, p. $769 \quad 455-489$.

770 Howard, K.A., Wooden, J.L., Barnes, C.G., Premo, W.R., Snoke, A.W., and Lee, S.-Y.,

771 2011, Episodic growth of a Late Cretaceous and Paleogene intrusive complex of 772 pegmatitic leucogranite, Ruby Mountains core complex, Nevada, USA:

773 Geosphere, v. 7, no. 5, p. 1220, doi: 10.1130/GES00668.1.

774 Huang, H., Lin, F., Schmandt, B., Farrell, J., Smith, R.B., and Tsai, V.C., 2015, The

775 Yellowstone magmatic system from the mantle plume to the upper crust: $\mathrm{v}$. 
348, no. 6236, p. 773-776.

777 Julia, J., Ammon, C.J., Herrmann, R.B., and Correig, A.M., 2000, Joint inversion of

778 receiver function and surface wave dispersion observations:

779 Kay, S.M., and Coira, B.L., 2009, Shallowing and steepening subduction zones,

780 continental lithospheric loss, magmatism, and crustal flow under the Central

781 Andean Altiplano-Puna Plateau: Geological Society of America Memoir, v. 204,

782 no. 11 , p. $1-32$, doi: $10.1130 / 2009.1204(11)$.

783 Kay, S.M., Coira, B., and Viramonte, J., 1994, Young mafic back arc volcanic rocks as

784 indicators of continental lithospheric delamination beneath the Argentine Puna

785 Plateau, central Andes: Journal of Geophysical Research, v. 99, no. B12, p.

$786 \quad 24323$, doi: 10.1029/94JB00896.

787 Kay, S.M., Coira, B., Wörner, G., Kay, R.W., and Singer, B.S., 2011, Geochemical,

788 isotopic and single crystal 40Ar/39Ar age constraints on the evolution of the

789 Cerro Galán ignimbrites: Bulletin of Volcanology, v. 73, no. 10, p. 1487-1511,

790 doi: $10.1007 / \mathrm{s} 00445-010-0410-7$.

791 Kennett, B.L.N., and Engdahl, E.R., 1991, Traveltimes for global earthquake location

792 and phase identification: Geophysical Journal International, v. 105, no. 2, p.

793 429-465, doi: 10.1111/j.1365-246X.1991.tb06724.x.

794 Kiser, E., Palomeras, I., Levander, A., Zelt, C., Harder, S., Schmandt, B., Hansen, S.,

795 Creager, K., and Ulberg, C., 2016, Magma reservoirs from the upper crust to the

796 Moho inferred from high-resolution Vp and Vs models beneath Mount St.

797 Helens, Washington State, USA: Geology, v. 44, no. 6, p. G37591.1, doi:

$798 \quad 10.1130 / G 37591.1$ 
799 Lebedev, S., Adam, J.M.C., and Meier, T., 2013, Mapping the Moho with seismic

800 surface waves: A review, resolution analysis, and recommended inversion

801 strategies: Tectonophysics, v. 609, p. 377-394, doi:

$802 \quad$ 10.1016/j.tecto.2012.12.030.

803 Lejeune, A., and Richet, P., 1995, Rheology of crystal-bearing silicate melts : An

804 experimental study at high viscosities K tcryst: Journal of Geophysical

805 research : Soild Earth, v. 100, no. B3, p. 4215-4229, doi: 10.1029/94JB02985.

806 Liang, X., Sandvol, E., Kay, S., Heit, B., Yuan, X., Mulcahy, P., Chen, C., Brown, L., Comte,

807 D., and Alvarado, P., 2014, Delamination of southern Puna lithosphere revealed

808 by body wave attenuation tomography: Journal of Geophysical Research: Solid

809 Earth, v. 119, no. 1, p. 549-566, doi: 10.1002/2013JB010309.

810 Lipman, P.W., and Bachmann, O., 2015, Ignimbrites to batholiths: Integrating

811 perspectives from geological, geophysical, and geochronological data:

812 Geosphere, v. 11, no. 3, p. 705-743, doi: 10.1130/GES01091.1.

813 Marsh, B.D., 1981, On the crystallinity, probability of occurrence, and rheology of

814 lava and magma: Contributions to Mineralogy and Petrology, v. 78, no. 1, p. 85-

8159 98, doi: $10.1007 /$ BF00371146.

816 Murray, K.E., Ducea, M.N., and Schoenbohm, L., 2015, Foundering-driven

817 lithospheric melting: The source of central Andean mafic lavas on the Puna

818 Plateau $\left(22^{\circ} \mathrm{S}-27^{\circ} \mathrm{S}\right)$ : Geological Society of America Memoirs , v. 212, no. 8, p.

819 139-166, doi: 10.1130/2015.1212(08).

820 Porter, R., Gilbert, H., Zandt, G., Beck, S., Warren, L., Calkins, J., Alvarado, P., and

821 Anderson, M.L., 2012, Shear wave velocities in the Pampean flat-slab region 
822 from Rayleigh wave tomography: Implications for slab and upper mantle

823 hydration: Journal of Geophysical Research: Solid Earth, v. 117, no. 11, p. 1-21, 824 doi: $10.1029 / 2012 J B 009350$.

825 Saleeby, J., Ducea, M.N., and Clemens-Knott, D., 2003, Production and loss of high826 density batholithic root, southern Sierra Nevada, California: Tectonics, v. 22, no. 827 6, doi: 10.1029/2002TC001374.

828 Sandvol, E., and Brown, L., 2007, SLIP - Seismic Lithospheric Imaging of the Puna 829 Plateau, International Federation of Digital Seismograph Networks, 830 doi:10.7914/SN/X6_2007.

831 Schoenbohm, L.M., and Carrapa, B., 2015, Miocene-Pliocene shortening, extension, 832 and mafic magmatism support small-scale lithospheric foundering in the 833 central Andes, NW Argentina: v. 1212, no. 9, p. 167-180, doi:

$834 \quad 10.1130 / 2015.1212(09)$.

835 Scire, A., Biryol, C.B., Zandt, G., and Beck, S., 2014, Imaging the Nazca slab and 836 surrounding mantle to $700 \mathrm{~km}$ depth beneath the central Andes (18 S to $28 \mathrm{~S}$ ), 837 in Geological Society of America Memoirs, p. 23-41.

838 Seccia, D., Chiarabba, C., De Gori, P., Bianchi, I., and Hill, D.P., 2011, Evidence for the 839 contemporary magmatic system beneath Long Valley Caldera from local 840 earthquake tomography and receiver function analysis: Journal of Geophysical 841 Research: Solid Earth, v. 116, no. 12, doi: 10.1029/2011JB008471.

842 de Silva, S.L., and Gosnold, W.D., 2007, Episodic construction of batholiths: Insights 843 from the spatiotemporal development of an ignimbrite flare-up: Journal of 844 Volcanology and Geothermal Research, v. 167, no. 1-4, p. 320-335, doi: 
846 Spica, Z., Legrand, D., Iglesias, A., Walter, T.R., Heimann, S., Dahm, T., Froger, J.L.,

847 R??my, D., Bonvalot, S., West, M., and Pardo, M., 2015, Hydrothermal and 848 magmatic reservoirs at Lazufre volcanic area, revealed by a high-resolution 849 seismic noise tomography: Earth and Planetary Science Letters, v. 421, p. 27$850 \quad 38$, doi: 10.1016/j.epsl.2015.03.042.

851 Takei, Y., 1998, Constitutive mechanical relations of solid-liquid composites in terms 852 of grain boundary contiguity: Journal of Geophysical Research, v. 103, no. 98, p. 853 18183-18203, doi: 10.1029/98JB01489.

854 Takei, Y., 2002, Effect of pore geometry on V P / V S : From equilibrium geometry to

855 crack: Journal of Geophysical Research, v. 107, no. B2, p. 2043, doi:

$856 \quad 10.1029 / 2001$ JB000522.

857 Tassara, A., and Echaurren, A., 2012, Anatomy of the Andean subduction zone:

858 Three-dimensional density model upgraded and compared against global-scale

859 models: Geophysical Journal International, v. 189, no. 1, p. 161-168, doi:

$860 \quad 10.1111 / \mathrm{j} .1365-246 X .2012 .05397 . x$.

861 Ward, K.M., Porter, R.C., Zandt, G., Beck, S.L., Wagner, L.S., Minaya, E., and Tavera, H., 862 2013, Ambient noise tomography across the Central Andes: Geophysical

863 Journal International, v. 194, no. 3, p. 1559-1573, doi: 10.1093/gji/ggt166.

864 Ward, K.M., Zandt, G., Beck, S.L., Christensen, D.H., and McFarlin, H., 2014, Seismic

865 imaging of the magmatic underpinnings beneath the Altiplano-Puna volcanic

866 complex from the joint inversion of surface wave dispersion and receiver

867 functions: Earth and Planetary Science Letters, v. 404, p. 43-53, doi: 
869 West, M., and Christensen, D., 2010, Investigating the relationship between pluton 870 growth and volcanism at two active intrusions in the central Andes, 871 International Federation of Digital Seismographic Networks, 872 doi:10.7914/SN/XP_2010.

873 White, S.M., Crisp, J.A., and Spera, F.J., 2006, Long-term volumetric eruption rates 874 and magma budgets: Geochemistry, Geophysics, Geosystems, v. 7, no. 3, doi: $875 \quad$ 10.1029/2005GC001002.

876 Wölbern, I., Heit, B., Yuan, X., Asch, G., Kind, R., Viramonte, J., Tawackoli, S., and 877 Wilke, H., 2009, Receiver function images from the Moho and the slab beneath 878 the Altiplano and Puna plateaus in the Central Andes: Geophysical Journal 879 International, v. 177 , no. 1, p. 296-308, doi: 10.1111/j.1365$880 \quad 246 X .2008 .04075 . x$.

881 Yáñez, G. a., Ranero, C.R., von Huene, R., and Díaz, J., 2001, Magnetic anomaly 882 interpretation across the southern central Andes $\left(32^{\circ}-34^{\circ} \mathrm{S}\right)$ : The role of the 883 Juan Fernández Ridge in the late Tertiary evolution of the margin: Journal of 884 Geophysical Research, v. 106, no. B4, p. 6325, doi: 10.1029/2000JB900337. 885 Yoshino, T., Takei, Y., Wark, D.A., and Watson, E.B., 2005, Grain boundary wetness of 886 texturally equilibrated rocks, with implications for seismic properties of the 887 upper mantle: Journal of Geophysical Research B: Solid Earth, v. 110, no. 8, p. 1$888 \quad$ 16, doi: $10.1029 / 2004 J B 003544$.

889 Zandt, G., Gilbert, H., Owens, T.J., Ducea, M., Saleeby, J., and Jones, C.H., 2004, Active 890 foundering of a continental arc root beneath the southern Sierra Nevada in 
891 California.: Nature, v. 431, no. 7004, p. 41-46, doi: 10.1038/nature02847.

892 Zandt, G., Leidig, M., Chmielowski, J., Baumont, D., and Yuan, X., 2003, Seismic

893 Detection and Characterization of the Altiplano-Puna Magma Body, Central

894 Andes: Pure and Applied Geophysics, v. 160, no. 3, p. 789-807, doi:

$895 \quad 10.1007 /$ PL00012557.

896 

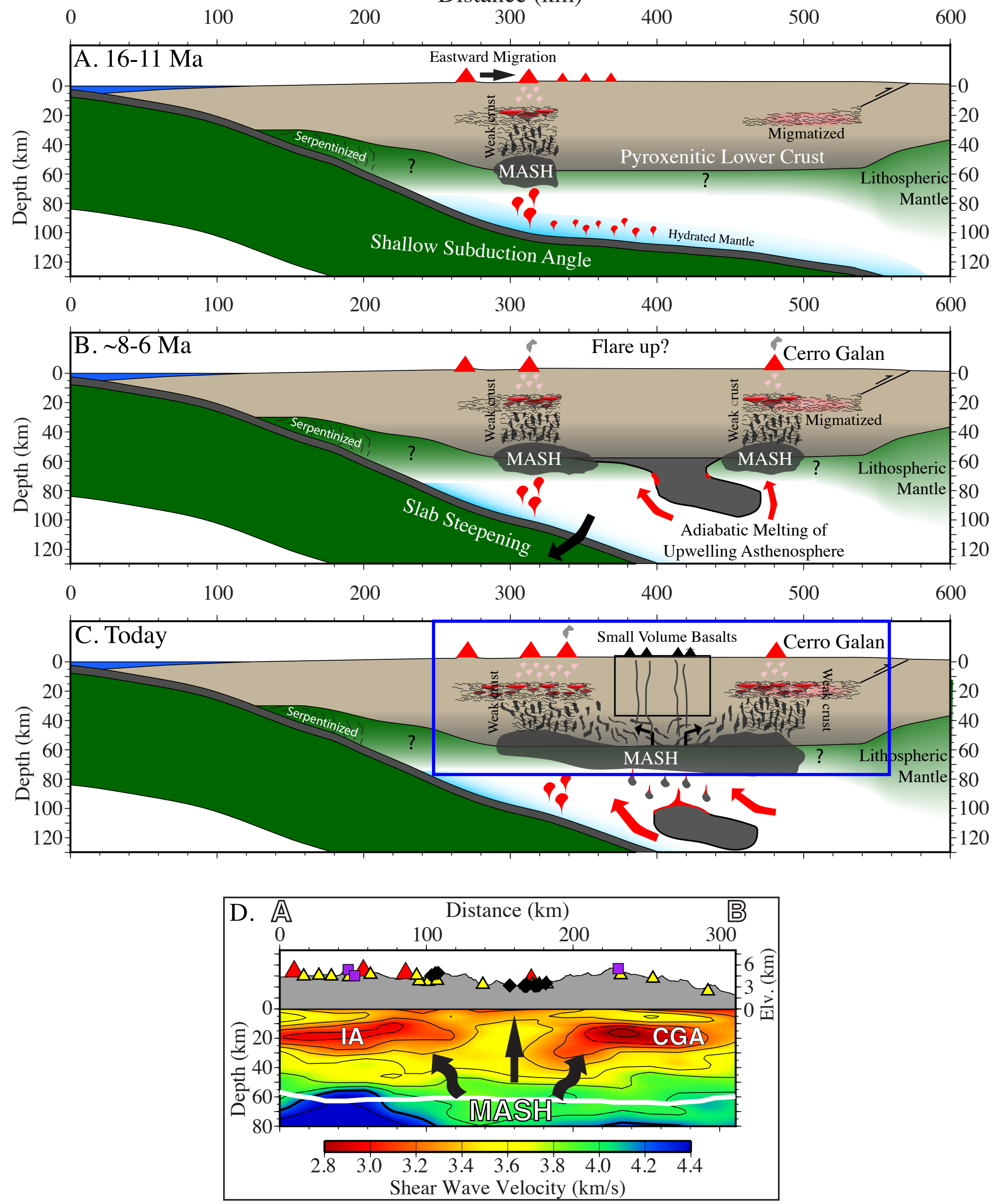